\title{
Evidence of Information Spillovers in the Production of Investment Banking Services
}

\author{
Lawrence M. Benveniste \\ Carlson School of Management \\ University of Minnesota \\ lbenveniste@csom.umn.edu
}

\author{
Alexander P. Ljungqvist \\ Stern School of Business \\ New York University \\ and CEPR \\ aljungqv@stern.nyu.edu
}
William J. Wilhelm, Jr.
Saïd Business School
Oxford University

william.wilhelm@sbs.ox.ac.uk

\section{Xiaoyun $\mathrm{Yu}^{*}$}

Kelly School of Business

Indiana University

xiyu@indiana.edu

Draft: August 21, 2001

\footnotetext{
\# This is a substantial revision of a previous draft. We thank Paul Seguin for numerous valuable insights and suggestions and Walid Busaba, Luigi Zingales, Pervin Shroff, and seminar participants at the NYSE-CEPR "Design of Primary Equity Market" conference (Capri 2000) and the University of Minnesota for helpful comments.

* Corresponding author. Department of Finance, Kelly School of Business, Indiana University, 1309 East Tenth Street, Bloomington, IN 47405-1701.
} 


\title{
Evidence of Information Spillovers in the Production of Investment Banking Services
}

\begin{abstract}
We present evidence that firms attempting IPOs learn from the experience of their contemporaries. These information spillovers affect revisions in offer terms and the decision whether to carry through with an offering. The evidence also supports the argument that IPOs are implicitly bundled as a means of promoting more equitable sharing of information production costs. One apparent consequence of this behavior is that while initial returns and IPO volume are positively correlated in the aggregate, the correlation is negative among contemporaneous offerings subject to a common valuation factor. These findings are consistent with the Benveniste, Busaba, and Wilhelm (2001) argument that the dynamics of volume and initial returns in primary equity markets reflect, at least in part, an institutional response to information externalities.
\end{abstract}

Key words: $\quad$ Initial public offerings; investment banking; information externalities; going public decision.

JEL classification: G32, G24

Draft: $\quad$ August 21, 2001 


\section{INTRODUCTION}

In the second half of 1999, at the height of the "dot.com" wave, 282 firms went public in the U.S. In the first half of 2001, only 46 firms went public. Ibbotson and Ritter (1995) document similar boom and bust patterns going back to 1960. Coupled with this pattern is the tendency for large initial returns during 'hot' markets [Lowry and Schwert (2000)]. Benveniste, Busaba, and Wilhelm (2001) attempt to explain these patterns with a model in which the central assumption is that potential issuers benefit from information about a common valuation factor that spills over from the marketing efforts of other firms attempting public offerings. Under some circumstances, conditioning on information spillovers leads potential issuers to attempt IPOs themselves and thereby set off a wave among firms subject to the common valuation factor.

But if information production is costly and becomes a public good during the marketing effort, any single firm has little incentive to lead the way. What then prevents the market from collapsing around the incentive for potential issuers to free-ride on one another? The explanation offered by Benveniste et al. (2001) is that given sufficient market power, investment banks resolve the coordination problem by implicitly 'bundling' IPOs and thereby enforcing more uniform sharing of the costs of information production. But they also show that this explanation implies negative correlation between average (percentage) initial returns and IPO volume among firms subject to a common valuation factor as there are more firms to share this indirect cost of information. This prediction stands in sharp contrast to the positive correlation observed for the IPO market at large.

In this paper, we investigate the consequences of clustering in the IPO market through the lens suggested by Benveniste et al. Drawing on 6,181 IPOs brought to market in the U.S. between January 1985 and December 2000, we find considerable evidence of information spillovers influencing decisions regarding whether a firm will complete an attempted IPO and if so how the offering is priced relative to prior expectations. We also find evidence that initial returns are smaller, the more firms sharing a common valuation factor go public in short succession. We 
interpret this as evidence of bundling. In sum, the results are consistent with the presence of information externalities and the conjectured institutional response suggested by Benveniste et al., and complementary to those of Lowry and Schwert (2000). Lowry and Schwert document strong autocorrelation in initial returns and a pronounced direct effect of initial returns on future IPO volume. They interpret these patterns as evidence that potential issuers learn from the experience of other IPOs, as reflected in positive initial returns, and so are more likely to follow with their own offering.

\section{THEORY AND EMPIRICAL MODEL DEVELOPMENT}

A growing body of literature considers the implications for industrial organization arising from information externalities in the production of investment banking services. Tufano (1989) and Persons and Warther (1997) observe that financial innovations are easily reverse-engineered and therefore difficult for pioneering firms to fully internalize their benefits. Like Benveniste, Busaba and Wilhelm (2001), Hoffman-Burchardi (2001) argues that information externalities diminish the incentive of innovators or issuing firms to undertake information production in the first place. Persons and Warther (1997) suggest that the equilibrium response to the externality problem will be a market structure dominated by a few key intermediaries who thereby gain the leverage necessary to internalize the benefits of pioneering efforts. Benveniste et al. establish the limits of the intermediary's leverage in the context of IPOs and in doing so, arrive at a set of predictions regarding pricing and volume dynamics in primary equity markets.

The Benveniste et al. model assumes that the realized value of a firm's project has two sources of uncertainty: a factor common to all firms within a particular "industry", and a firm-specific or idiosyncratic factor. The project can be financed either privately or through an initial public equity offering. Other things equal, the IPO is preferred for liquidity, risk sharing and visibility 


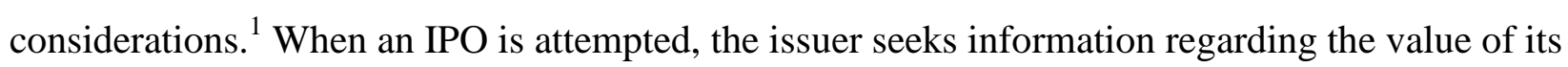
project from investors who have engaged in costly information production. 2 Conditional on this feedback, the issuer either completes the IPO and funds its project, or withdraws. If the offering is withdrawn, the issuer has the option to fund the project privately or reject the project. ? $^{\text {Presumably, }}$, this enables firms to avoid investments in projects that unconditionally appeared positive NPV, but conditional on information gained through the bookbuilding effort, are revealed as negative NPV projects.

Whether the firm completes or withdraws its IPO, information revealed through its bookbuilding effort is assumed to enter the public domain. The immediate consequence of this assumption is a coordination problem. This arises from the information externality produced by the first firm subject to a common valuation factor attempting an IPO. If pioneers bear the burden of compensating investors for costly information production, there is little incentive among firms subject to the common factor to be the first mover. ${ }^{4}$ Welfare declines as firms are discouraged from seeking out a potentially lower-cost source of funding.

Benveniste et al. argue, however, that barriers to entry might enable investment banks to enforce a more equitable sharing of information production costs by implicitly bundling IPOs that share a common valuation factor. If underpricing reflects compensation to investors for their

\footnotetext{
${ }^{1}$ The literature treats IPOs as being subject to both direct and indirect costs. The former include underwriting, legal and registration fees which generally are small relative to the indirect cost of 'underpricing' generally associated with some form of asymmetric information. Although Benveniste et al. abstract from the latter, in their footnote 9 they discuss the generality of the model's predictions when extended to include the information acquisition game envisioned by Benveniste and Spindt (1989) and subsequent related work. Empirical evidence of strategic behavior in the 'bookbuilding' process is perhaps best evidenced by the 'partial adjustment phenomenon' documented by Hanley (1993). For more recent and extensive evidence, see Cornelli and Goldreich (2001) and Ljungqvist and Wilhelm (2001). ${ }^{2}$ See Sherman and Titman (2001) for a formal model of costly information acquisition in the bookbuilding context.

${ }^{3}$ In practice, withdrawal of a proposed offering is a common response to negative feedback. Dunbar (1998) finds that $29 \%$ of the firm-commitment offerings registered with the SEC in a sample drawn from 1979-1982 were terminated prior to receiving SEC approval. Benveniste and Busaba (1996) report a 14\% termination rate for firm-commitment offerings registered between 1988 and 1994, and Busaba, Benveniste, and Guo (2001) observe a similar rate for the 1984-94 period.

${ }^{4}$ Maksimovic and Pichler (2001) consider the case where firms make strategic decisions regarding the timing of a public offering.

${ }^{5}$ There is a gathering consensus that personal relationships and reputational considerations along with the industry's dependence on (human) assets over which firms have weak property rights preclude perfect competition among
} 
information production costs, banks can spread the burden of information production by 'smoothing' underpricing across a 'wave' of IPOs subject to the valuation factor. Thus followers are made to bear some of the information production costs investors incurred in the pioneer's IPO.

Other things equal, the more followers there are, the more broadly information costs can be shared, and so underpricing should decrease in the size of the wave.

Benveniste et al.'s analysis highlights that IPOs by firms subject to a common valuation factor are not independent events. Dependence suggests a variety of implications regarding how information spillovers influence the structure of the investment banking industry and the time series patterns in the indirect costs of going public. The structural econometric model outlined in the remainder of this section is designed to shed light on these implications. A precise empirical specification is provided after we describe the data and discuss several measurement concerns.

\section{Bookbuilding with information spillovers}

Benveniste et al. build on theory stemming from Benveniste and Spindt (1989). This body of theory predicts that an issuer conditions its offer price and share quantity (or total proceeds) on information acquired through its underwriter's bookbuilding effort. For the purposes of this study, we define the bookbuilding phase of the offering as the period between the registration date (when an indicative price and offer amount are established) and the offer (or withdrawal) date. A growing body of empirical research that focuses on revisions to indicative prices supports the hypothesis that firms acquire information from investors through their own bookbuilding efforts. ${ }^{6}$

Benveniste et al. make the additional prediction that firms also learn from the bookbuilding efforts of contemporaries that are subject to the same valuation factor. Our empirical work

investment banks. There is less agreement regarding the consequences of imperfect competition. See Persons and Warther (1997), Anand and Galetovic (2000), Loughran and Ritter (2000), and Pichler and Wilhelm (2000).

${ }^{6}$ See Hanley (1993), Hanley and Wilhelm (1995), Cornelli and Goldreich (2001), Ljungqvist, Jenkinson, and Wilhelm (2001), and Ljungqvist and Wilhelm (2001). 
investigates learning in response to information revealed via contemporaries' withdrawal and pricing decisions, their underpricing experience, and the rate of new registrations by related firms. Learning, in turn, should be reflected in a firm's own revisions to its offer terms, including the possibility of withdrawal.

The indicative price range and quantity included in an issuer's registration (S-1) filing should reflect all public information, including any thrown off by contemporaries' bookbuilding efforts already underway. However, Lowry and Schwert (2001) provide evidence that indicative prices do not fully incorporate such information. Thus, in modeling the learning that takes place during the bookbuilding phase we distinguish between common-factor information that is already available on the registration date, and that which spills over between the registration and offering (or withdrawal) date.

Although not a direct implication of the Benveniste et al. model, we expect the effect of information spillovers to be stronger among pioneers and early followers than among firms later in an IPO wave. This prediction about the dynamics of learning rests on uncertainty about the common valuation factor declining over a sequence of offerings as more information enters the public domain. If this assumption holds, later offerings are more likely to incorporate common-factor information produced by earlier IPOs in their indicative offer terms and therefore will not exhibit as strong dependence on the marketing efforts of their immediate contemporaries.

In this model of learning, two potential control variables warrant special attention. If firm valuation is a function of both common and idiosyncratic factors and our goal is to study how common factor information is acquired and used by issuing firms, it is necessary to control for idiosyncratic uncertainty. We therefore include a range of uncertainty proxies previously used in the literature. Secondly, there is considerable theory and evidence suggesting that underwriters differ in their abilities and we expect this to map into the learning occurring during the bookbuilding process [Carter and Manaster (1990)]. However, controlling for these differences among underwriters is 
complicated if issuers select their underwriter conditional on knowledge of these differences. We provide a more detailed discussion of endogenous underwriter choice below.

This discussion suggests a model of the following general form for individual firm learning during the bookbuilding phase:

\section{Proceeds revisions $=f_{1}$ (spillovers from contemporaneous IPOs (pre-filing and bookbuilding phase), issuer's position in an IPO wave, idiosyncratic uncertainty, underwriter choice)}

\section{Clustering and initial returns}

Our initial return model embodies the Benveniste and Spindt (1989) hypothesis that discounted share allocations provide (strategic) compensation for information revealed by institutional investors during the bookbuilding phase. Proceeds revisions serve as the measure of information acquired during the bookbuilding phase. Since the preceding discussion implies the endogeneity of proceeds revisions, an instrumental variables estimate of revisions, obtained by estimating the revision function $f_{1}(\cdot)$, will serve as the explanatory variable. As a consequence, information spillovers enter the initial return model indirectly as instruments for proceeds revisions.

The primary implication for initial returns from Benveniste et al. (2001) is the potential for smoothing across IPOs related by a common factor. Smoothing occurs if investment banks implicitly bundle IPOs to resolve coordination problems. One observable consequence of bundling should be a negative correlation between IPO volume and initial returns among firms subject to a common valuation factor. Thus Benveniste et al. predict a reversal of the positive correlation observed among IPOs at large when focusing on IPOs sharing a common valuation factor. Specifically, we expect bundling to lead to the following patterns: (i) lower percentage discounts on 
average as the total cost of information production is spread across a larger bundle of firms, and (ii) a relatively smooth distribution of discounts across bundled firms.

On the other hand, it stands to reason that there are limits to the bundling argument. IPOs in close proximity might be bundled effectively, but it seems less plausible that transactions widely separated in time could be, even if they were subject to a common valuation factor. Thus we expect the negative relation between initial returns and the number of related transactions only for deals early in the sequence. Experimentation with the definition of 'early' should therefore yield insights regarding the limits to the type of bundling Benveniste et al. envision.

As control variables in the initial return model we include measures of underwriter choice and uncertainty surrounding the issuing firm. Both have previously been shown to influence initial returns [Beatty and Ritter (1986), Carter and Manaster (1990)]. Thus, our initial return model takes the following general form:

Initial Returns $=f_{2}$ (proceeds revisions, bundling effects, underwriter choice, firm-specific uncertainty, probability of withdrawal)

Following Busaba, Benveniste, and Guo (2001), we also include a measure of the probability of withdrawal to control for the possibility that a credible threat to obtain alternative financing provides bargaining power that diminishes any rents captured by informed investors in the form of initial returns. Controlling for this possibility is complicated by the endogeneity of the firm's choice between completion and withdrawal conditional on information acquired during the bookbuilding phase. We address this concern using a two-stage Heckman procedure for which the first-stage probability model is developed next. 
Information spillovers and the probability of withdrawal

Data censoring associated with withdrawn offerings complicates the estimation of the effects of asymmetric information on the underpricing cost of going public. Recent studies take this problem into consideration [e.g. Busaba, Benveniste, and Guo (2001)] but ignore information spillovers. But if common factor information enters the public domain via the marketing of related IPOs, then the probability of completing an IPO will be conditioned on information spilling over from both its own marketing effort and those of contemporaneous offerings. Other things equal, we expect contemporaneous positive (negative) information spillovers to increase (diminish) the likelihood that a firm will complete its own offering.

We also predict that the probability of completion is related to the issuer's position in an IPO wave. If we again assume that uncertainty regarding the common valuation factor diminishes as additional firms attempt an IPO, then the marginal information generated by issuers late in a wave is less likely to be sufficiently negative to induce withdrawal. Other things equal, therefore, pioneers are more likely to withdraw than followers.

Finally, we admit the possibility that the issuer's bank can influence the likelihood of completion. This can take two forms. If reputation is linked to the gate-keeping role envisioned by Benveniste et al., more reputable banks should be better able to control free-riding among issuers subject to a common valuation factor. Thus, they should be associated with fewer withdrawals among (pioneering) firms if reputation is correlated with a capacity for spreading the (indirect) costs of acquiring information across subsequent offerings. Secondly, it is also possible that more reputable banks deal only with less risky firms for which the likelihood of acquiring substantial negative information during the bookbuilding process is low. Either argument predicts a positive correlation between underwriter reputation and the likelihood of completing an attempted offering.

These arguments suggest the following probability model to test for dependence between information spillovers and the likelihood of completing an attempted IPO: 
$\operatorname{Pr}($ Completion $)=f_{3}$ (information spillovers, issuer's position in an IPO wave, firm-specific uncertainty, underwriter choice)

\section{Underwriter choice}

Equations [1]-[3] control for the issuer's choice of underwriter. We model this choice explicitly to avoid problems stemming from endogeneity bias. For example, Habib and Ljungqvist (2001) show that treating underwriter choice as exogenous leads to the erroneous inference that more prestigious underwriters are associated with higher underpricing in the U.S. in the early 1990s. The main determinant of underwriter choice that we consider is expected offer size. Habib and Ljungqvist argue that reductions in underpricing are worth more to the issuer's owners at the margin, the greater the issue size. Therefore, issuers are more likely to take costly actions designed to reduce underpricing - such as hiring a top-tier bank - the more money they intend to raise. In addition to expected offer size, we control for firm-specific valuation uncertainty (riskier firms may have more to gain from information production and so may be more likely to hire a top-tier bank), and for the state of the IPO market in the lead-up to a firm's S.E.C. filing. (Theory gives us no guidance as to the influence of the state of the IPO market on underwriter choice, but exploring a variety of possible specifications we invariably find significant effects.) Our model of underwriter choice is

Underwriter Rank $=f_{4}$ (filing amount, firm-specific uncertainty, pre-filing state of the IPO market) 


\section{SAMPLE AND DATA}

\section{III.A The data set}

The sample consists of firms that completed or withdrew an initial public offering between January 1985 and December 2000. Thomson Financial's SDC database lists 8,151 completed IPOs during 1985-2000, from which we excluded 951 unit offers, 721 closed-end funds (including REITs), 175 ADRs, and 71 limited partnerships. ${ }^{\mathrm{W}}$ We then checked the remaining 6,233 offerings for misclassifications. This led to the following exclusions: 40 companies which were already traded at the time of their offering, 14 offers which were in fact units, 13 that were in fact REITs, 9 that listed exclusively outside the U.S., 8 that were in fact closed-end funds, 4 firms which were not operating companies, 2 offerings that were double-counted, and 2 that were offerings of preferred stock. This gives a sub-total of 6,141 IPOs. To this we added 40 companies which SDC listed in a previous download but which were excluded from recent listings. We verified that all 40 are bona fide IPOs meeting the above criteria. The final sample of completed IPOs consists of 6,181 observations.

SDC also lists 1,427 withdrawn IPO registrations between January 1985 and December 2000. Further investigation revealed that five of these were not bona fide IPO registrations. Thus our sample of withdrawn IPOs consists of 1,422 observations.

Using the S.E.C.'s EDGAR service, Investment Dealers Digest, the S\&P Corporate Directories, and news sources in Reuters and Lexis-Nexis, we double-checked and hand-filled several data items in SDC relating to filing information (filing dates, withdrawal dates, amount to be raised, initial price range, number of shares to be offered), and firm characteristics (SIC code, VC backing, founding year, earnings per share in the most recent 12-month period before filing). In 194 cases, we were unable to find a specific withdrawal date in either SDC or our other sources. Lerner (1994, pp. 312-313) describes the procedure for withdrawing an IPO registration. A registration

\footnotetext{
${ }^{7}$ Unlike Loughran and Ritter (2000) we do not exclude IPOs with low offer prices. Dropping the $4.4 \%$ of sample firms with offer prices below $\$ 5$ does not in any way alter our results.
} 
which has not been formally withdrawn is typically deemed withdrawn by the S.E.C. 270 days after the last amendment date. This is the withdrawal date we use in the 194 cases.

Initial returns are calculated using the first-day closing price reported by the Center for Research in Securities Prices (CRSP) if it is available within 6 days of the offer date. Otherwise, we rely on SDC for the first-day closing price.

\section{III.B Summary statistics}

Table 1 reports summary statistics for firm and offering characteristics, broken down by completed and withdrawn IPOs. The average completed IPO (which we refer to as an 'IPO firm') is almost 13 years old at the time of its offering, though we lack age data for nearly a third of the sample. $37 \%$ of IPO firms are venture-backed, and 34\% operate in what we refer to as 'nascent industries' (3-digit SIC codes $283,357,366,367,381,382,383,384$, and 737 , covering the pharmaceuticals, computing, electronics, medical and measurement equipment, and software industries). Industry affiliation is the only firm characteristic we have for withdrawn IPOs. $30 \%$ of withdrawers come from nascent industries, a fraction which is marginally lower than for IPO firms $(p=0.052)$. (To conserve space, we do not report test statistics for differences between completed and withdrawn IPOs in Table 1, leaving formal test results to Table 5 which reports the Heckman estimation results for the probability of completing an IPO. Here, we report $p$-values for difference tests in the text, where appropriate. All test statistics are adjusted for the upward bias caused by time clustering, by assuming that observations are independent for companies at different points in time, but not necessarily for companies which go public or withdraw in the same month.)

As a measure of valuation uncertainty, we compute the extent to which the expected offer price reflects future growth opportunities $(P V G O)$ rather than earnings from assets in place. Specifically, we compute an index $\frac{P V G O}{\mathrm{E}[P]} \equiv \frac{\mathrm{E}[P]-E P S / R}{\mathrm{E}[P]}$, where $\mathrm{E}[P]$ is the expected offer price (the mid 
point of the filing range) and EPS is earnings per share in the most recent 12-month period before filing, which we capitalize at the industry cost of capital $R$ (the sum of the Fama-Bliss one-month risk-free rate in the filing month and the Fama-French (1997) CAPM risk premium estimate for that

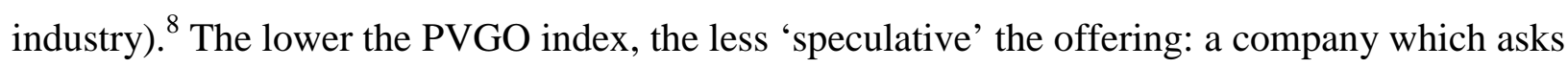
investors to pay $\mathrm{E}[P]$ mainly in return for rights to earnings from assets in place is, presumably, easier to value than a company whose offer price mainly reflects future growth opportunities. To illustrate, the typical manufacturing company has positive earnings and intends to go public mainly to reduce debt and so has a low PVGO index. The typical biotechnology or Internet company has negative earnings and intends to go public to finance its business plan and so has a high PVGO index. In our sample, the average company has an index value of 0.71 , so $71 \%$ of its expected offer price reflects future growth opportunities rather than assets in place.

The lower part of Table 1 reports the main offering characteristics. To measure underwriter reputation, we use the ten-point scale in Carter and Manaster (1990) and Carter, Dark, and Singh (1998). This averages 6.88 for IPO firms and a significantly lower 6.08 for withdrawers $(p=0.001)$. The average IPO firm files to raise more money than the average withdrawer, \$61 million vs. \$51.6 million ( $p=0.026$ ). Table 1 also reports changes in offering characteristics, for IPO firms only, that occur between the registration and offer date. The average firm revises its proceeds up by $3.87 \%$, from $\$ 61$ million to $\$ 63.6$ million, with most of the revision reflecting changes in the number of shares $(+2.47 \%)$ rather than price revisions $(+0.96 \%)$. Finally, initial returns average $20.2 \%$ in our sample.

\footnotetext{
${ }^{8}$ We handfill missing and suspect $E P S$ from S.E.C. filings, subsequent 10-Ks, or news sources. If $E P S$ is negative, we set $P V G O / \mathrm{E}[P]$ equal to 1 . If capitalized $E P S$ is greater than $\mathrm{E}[P]$, we set $P V G O / \mathrm{E}[P]$ equal to zero. $P V G O / \mathrm{E}[P]$ is thus bounded between 0 and 1.
} 
Information spillovers should be stronger amongst firms sharing a common valuation factor. We do not observe the common factor directly, so we investigate industry affinity, conjecturing that firms in the same or related industries are more likely to share a common factor. A straightforward way to define industry affinity is by SIC code. While this may accurately reflect commonalities in output, it has the drawback of ignoring functional or vertical relationships. Functional relationships may bind firms with different outputs but similar production or business processes. Vertical relationships may bind firms at different stages in the value chain. In either case, the IPO of a related company may generate valuation-relevant information. For instance, the positive reception for Netscape's IPO in 1995 presumably affected not only the IPO plans of firms in the same output space (browsers), but also of web retailers, software developers, server manufacturers and so on. Such firms do not necessarily share Netscape's SIC code even at the one-digit level.

Instead of SIC codes, we therefore use a set of industry aggregations derived by Fama and French (1997) in the context of estimating industry costs of capital. Fama and French aggregate firms by 4-digit SIC code into 48 industries. In Table 2 we show the corresponding industry breakdown of our IPO and withdrawer samples.

\section{III.C Spillovers and market conditions}

We attempt to capture information spillovers by measuring contemporaries' 1) proceeds revisions and 2) initial returns, and the rate of 3) new registrations and 4) withdrawals. Contemporaries are defined as firms in the same Fama-French industry which file/complete/withdraw an IPO between firm $i$ 's filing date and its offer or withdrawal date (the 'bookbuilding phase'). In addition, we allow 
for information spillovers from the period before firm $i$ 's filing date. We consider different prefiling windows but report descriptive statistics only for a 3-month window.

For each information spillover metric, we report the standard deviation alongside the mean, as a measure of the noise in the information generated by contemporaries. To measure the rate of new registrations, we compute the aggregate filing amount of all new registrants in the same FamaFrench industry during firm $i$ 's bookbuilding phase as well as the 'relative filing amount' (the aggregate filing amount in a Fama-French industry divided by the aggregate filing amount of new registrants across all industries). To measure the rate of withdrawals, we compute the absolute gross proceeds withdrawn as well as the 'relative withdrawal frequency' (the number of withdrawers during firm $i$ 's bookbuilding phase, divided by the number of firms with active registrations at the time of firm i’s S.E.C. filing).

In addition to IPO-specific spillovers, we investigate the influence of stock market conditions. We use a market-wide index (the equally-weighted NYSE-AMEX-NASDAQ return from CRSP) and an industry-specific index. The latter is computed as the equally-weighted return on firms in a particular Fama-French (1997) industry, using the universe of firms available in CRSP. We also compute the relative return, which equals $(1+$ industry return $) /(1+$ market return $)$. Relative returns greater than 1 indicate a Fama-French industry outperforming the market as a whole. (We do not attempt any risk adjustment given the short windows we consider.)

Table 3 reports the spillover metrics and market conditions broken down by completed and withdrawn IPOs, for the three months pre-filing (Panel A) and the bookbuilding phase (Panel B). To illustrate the information in the table, consider firms that subsequently complete an IPO. These file their S-1s after a three-month period which saw an average of ten firms in their industry go public,

\footnotetext{
${ }^{9}$ We use pre-1985 data from SDC to compute variables in three-month windows that extend back into 1984. Similarly, our measures of IPO activity during the year 2000 includes companies which were in registration in 2000 but had neither completed nor withdrawn their IPO by December 2000 and so weren't themselves sample companies.
} 
which experienced average initial returns of $20.9 \%$ after revising their proceeds up by an average of $6.8 \%$; while thirteen new registrations were filed for average intended proceeds of $\$ 51$ million, representing $7.2 \%$ of the aggregate proceeds filed across industries; and only one firm withdrew, taking \$22.3 million on average off the table. These pre-filing IPO conditions are statistically indistinguishable in the subsamples of IPO firms and subsequent withdrawers.

Pre-filing market conditions, on the other hand, differ significantly. The average IPO firm files after a three-month return of $12.6 \%$ on the market index and $11 \%$ on the industry index, a relative return of 0.986 . The average withdrawer files after a three-month return of $7.3 \%$ on the market index and $8.8 \%$ on the industry index, a relative return of 1.012 . While the relative return in either case is not significantly different from $1(p=0.108$ and $p=0.391)$, the difference in relative returns across the subsamples is significant $(p<0.004)$. This indicates that subsequent withdrawers file after particularly strong relative performance in their industry.

As Panel B shows, over the bookbuilding phase, the IPO market is considerably cooler for withdrawers than for IPO firms. Proceeds revisions for companies in the same industry average 4.6\% for the IPO firms and only $0.8 \%$ for withdrawers. This difference is significant at $p<0.001$. The variations in proceeds revisions and underpricing are significantly greater for the withdrawers ( $p<0.001$ and $p=0.035$, respectively), indicating a noisier environment in the runup to withdrawal. There are significantly more contemporaneous withdrawals while withdrawers build their books (9 versus $2, p=0.002$ ). Fully $43.9 \%$ of the firms in the same industry that were in active registration at the time the average withdrawer filed its $\mathrm{S}-1$ cancel their offerings during its bookbuilding phase, compared to only $9.3 \%$ for the average IPO firm $(p<0.001)$. On the other hand, there are more new registrations, and for larger amounts on average, during the bookbuilding phase of subsequent withdrawers $(p<0.001)$, though since the relative filing amount is the same $(p=0.459)$, this merely indicates a general increase in IPO activity. 
Looking at stock returns, the $20.6 \%$ market return during withdrawers' bookbuilding phase stands out, but this is in large part driven by the longer time these firms spend in registration relative to IPO firms ( 285 vs. 75 days on average, $p<0.001$ ). More telling is the relative return. During the average IPO firm's bookbuilding phase, its Fama-French industry index outperformed the equallyweighted market index by $0.98 \%$ (significant at $p<0.042$ ), compared to $-2.54 \%(p=0.117)$ for withdrawers. This difference in relative returns is significant at $p=0.018$.

In sum, compared to withdrawers, firms completing their IPOs face an IPO market in which their contemporaries have larger proceeds revisions and withdraw less often, and the information spilling over from other offerings is less noisy, while their industry index does well compared to the market index.

\section{III.D IPO waves}

As noted earlier, spillover and bundling effects should be stronger at the beginning of a sequence of IPOs sharing a common valuation factor (an 'IPO wave') than later on. We therefore need to control for where in an IPO wave an offering occurs. We consider three different ways to identify the start of a new wave. For each Fama-French industry, we identify all S.E.C. filings not preceded by filings in the same industry in the previous 180, 120, or 90 days (the 'pre-wave window'). We denote such filers 'pioneers'. All other filers are 'followers'. We distinguish between 'early' and 'late' followers in three different ways. Early followers are those filing within 90, 180, or 360 days of a pioneer's filing date. For instance, Scientific Computer Systems, which filed on October 2, 1984, was the first company in the Fama-French 'Comps' industry to file for an IPO in more than 13 months, making it a pioneer. It was followed by 4, 7, and 18 other filings during the next 90 , 180, and 360 days. We use these count measures to test the hypothesis that underpricing is lower, the more contemporaneous offerings an IPO can be bundled with. 
Depending on the assumed length of the pre-wave window, Table 4 documents anywhere from 311 to 668 distinct IPO waves in our sample. A disproportionate number of these were started by firms which subsequently withdrew, consistent with pioneers facing a high degree of uncertainty when approaching the IPO market. The right-hand panel of Table 4 shows the distributions of early followers under each definition. For instance, with the 180-day pre-wave window, there are an average of $.9,1.8$, and 3.7 early followers during the next 90, 180, and 360 days.

\section{ESTIMATION RESULTS}

\section{The probability of completing the IPO}

Table 5 reports the results of our base-line specification summarized in equations [1]-[4]. Equation [3] relates the probability that an offering will be completed to measures of information spillovers during the bookbuilding phase, the offering's position in the IPO wave, a control for firm-specific uncertainty (nascent industries), and the reputation of the underwriter. Underwriter reputation is assumed to be endogenous, so we first estimate a regression of equation [4]. Column (1) of Table 5 reports the results. The dependent variable is the ten-point Carter-Manaster scale, and the explanatory variables are the log of the filing amount, a dummy for nascent industries to control for differences in firm-specific uncertainty, and two pre-filing spillover variables to control for the state of the IPO market. The explanatory power of the regression is very high, in view of the $R^{2}$ of 39.1\%. As predicted, intended offer size is a highly significant determinant of underwriter choice, with a $t$-statistic of 36 (adjusted for time clustering). To illustrate the economic magnitude of the effect, consider a one standard deviation increase in (the log of) intended offer size from the sample mean, holding all other covariates at their respective means. This increases the underwriter rank chosen from 6.82 to 8.76 .

Firms in nascent industries are also, as predicted, more likely to choose more prestigious underwriters. The first pre-filing spillover variable indicates that firms choose less prestigious 
underwriters, the higher were recent initial returns in their Fama-French industry in the three months before their filing. This effect is very strong statistically $(p<0.001)$, though the economic significance is modest: a two-quartile increase in prior initial returns from the first quartile is associated with a reduction in underwriter rank from 6.9 to 6.81. A possible explanation for the negative sign is that issuers perceive less need for underwriter certification when investors are demonstrably willing to pay high prices for IPOs in their industry. We also find that firms choose more prestigious underwriters when their industry has accounted for a larger fraction of overall IPO activity in the previous three months $(p<0.001)$, though again the economic significance is relatively modest.

From this regression equation, we generate the instrumental variable for underwriter reputation included in the probit regression reported in column (2). Its coefficient estimate shows that firms lead-managed by more prestigious underwriters are more likely to complete an IPO $(p=0.033)$. The measures of information spillovers during the bookbuilding phase all have the expected sign and all but one are highly significant $(p<0.001)$. Specifically, companies are more likely to complete an offering, the more their contemporaries revise their proceeds upward and the greater contemporary underpricing. Increases in the variation of these measures reduce the probability of completion, consistent with our prediction that information spills over more easily the less noisy the environment. An increase in the relative withdrawal frequency (the number of withdrawers during firm $i$ 's bookbuilding phase, divided by the number of active registrations at the time of firm $i$ 's S.E.C. filing) reduces the probability of completion. ${ }^{10}$ Finally, stronger relative returns in firm $i$ 's industry increase the probability of completion. The only spillover measure having no significant

\footnotetext{
${ }^{10}$ While a Heckman procedure does not require an identifying variable (a variable included only in the selection equation and not in the second-stage regression), the presence of an identifying variable lessens the dependence on functional form to identify the model. We treat the relative withdrawal frequency as our identifying variable in the Heckman, and so exclude it from the second-stage regression for initial returns. Including it there does not, however, alter our findings.
} 
effect is the relative filing amount (the aggregate filing amount of all new registrants in the same Fama-French industry divided by the aggregate filing amount of registrants across all industries).

The two dummies for a deal's position in the IPO wave indicate that pioneers are $14.6 \%$ and their early followers $5.5 \%$ less likely to complete their offerings compared to deals filed later in a wave. This is consistent with firms in the early part of an IPO wave facing a higher degree of uncertainty when approaching the IPO market.

Since the proceeds revision and initial return equations [1] and [2] are estimated over the subsample of completed offerings only, we augment the underwriter choice equation with additional right-hand side variables that were not available for the withdrawn offerings included in column (1). The results of the augmented underwriter choice regression are shown in column (3). In addition to the effects discussed earlier, we find that VC-backed companies choose significantly more prestigious underwriters, and that more speculative offerings (as measured by our PVGO index) are lead-managed by less prestigious underwriters. 11

\section{Proceeds revisions}

Equation [1] relates a firm's proceeds revision to spillovers from contemporaneous offerings and its position in the IPO wave, controlling for firm characteristics and underwriter reputation. In addition to spillovers from contemporaries, we allow for the possibility of spillovers from offerings in the three months before filing. These should be insignificant to the extent that they are already reflected in the preliminary deal terms at filing. The 2SLS results are reported in column (4). The positive and significant coefficient estimated for the Carter-Manaster rank $(p=0.003)$ indicates that more prestigious underwriters are associated with greater positive revisions in proceeds and so differ in

\footnotetext{
${ }^{11}$ Our results for equations [1] and [2] are unaffected whether we instrument underwriter choice using the results in column (1) or column (3).
} 
their abilities, as predicted. Economically, the effect is very large: increasing the (instrumented) underwriter rank by one standard deviation from the mean of 6.96 would increase the log of proceeds revision from the sample mean of $-0.72 \%$ to $6.85 \%$. The effect remains positive if we do not treat underwriter reputation as endogenous, but the coefficient declines by $76 \%$, or more than two standard errors. This illustrates the extent of endogeneity bias. A formal Durbin-Wu-Hausman test rejects the null of exogeneity at $p=0.019$.

The pre-filing spillover measures are invariably insignificant. This suggests that information arising from other offerings in the three months preceding filing is taken into account at the time of filing and so does not affect subsequent revisions. 12

During the bookbuilding period, information generated by other offerings in the same industry appears to spill over and affect sample firms' proceeds revisions. In particular, firms' revisions to proceeds increase with the proceeds revisions $(p<0.001)$ and initial returns $(p<0.001)$ of their contemporaries, and with the return in their industry relative to the market return $(p<0.001)$. Economically, the magnitude of these effects ranges from increases of 3.5 to 4.8 percentage points for one standard deviation increases in the spillover variables. The rates of new registrations and withdrawals, on the other hand, have no significant effect. In other words, these decisions appear to reveal no information beyond that revealed by the contemporaneous IPO marketing efforts on which they are presumably conditioned.

The coefficient estimated for the pioneer dummy (defined, as in Table 4, as the first IPO in a particular industry for at least 180 days) is positive and highly significant $(p=0.003)$. The estimate indicates that pioneers increase their proceeds by 5.5 percentage points more, on average, than follower firms. Given that the average proceeds revision is $-0.7 \%$, this is a large difference. Taken

\footnotetext{
${ }^{12}$ This contrasts somewhat with the findings of Lowry and Schwert (2001) who show that pre-filing information, in the form of market index returns measured over fixed 50-day windows before the effective day, affects price revisions in their sample.
} 
together with the negative coefficient in the withdrawal probit in column (3), this is evidence of an asymmetric response function for pioneers: they withdraw in response to negative information and increase their offer size in response to positive information. The early followers, by contrast, do not experience significantly different proceeds revisions (relative to later offerings), which is what we expect if they incorporate the pioneer's information production when filing their S.E.C. registrations.

To control for differences in valuation uncertainty, we include four company and offer characteristics: the log of the filing amount, two dummies for venture-backed IPOs and companies operating in 'nascent' industries, and the PVGO index. Companies that file larger amounts have smaller subsequent proceeds revisions $(p=0.002)$, mirroring the findings of Beatty and Ritter (1986) that larger offerings are less risky. Venture-backed companies are marginally less aggressively repriced $(p=0.081)$. We find no difference in revisions between nascent and other industries. Finally, proceeds revisions are larger the more speculative the offering, as measured by our PVGO index $(p=0.001)$. It is intuitive that more speculative offerings have more to learn during bookbuilding, though unconditionally such learning could be either positive or negative. However, the coefficients in column (4) are estimated conditional on not having withdrawn, so it makes sense that more speculative offerings on average learn positive news and so revise their proceeds up.

In view of the $R^{2}$ of $9.3 \%$, a large amount of variation in proceeds revisions remains unexplained. This points to the importance of private (unobservable) information acquired from informed investors during bookbuilding [Benveniste and Spindt (1989)]. Information on the evolution of the book - which is not generally available to researchers [but see Cornelli and Goldreich (2001)] - would presumably help account for this unexplained variation.

Because the $R^{2}$ reported in Table 5 is based on a regression that includes variables other than information spillover measures, it is not a direct estimate of the importance of information 
spillovers alone. Dropping all non-spillover variables, we obtain an $R^{2}$ of $8.3 \%$, which gives us a better sense of how much information spillovers contribute to the price discovery process in IPOs.

\section{Initial returns}

Equation [2] relates a firm's initial return to its proceeds revision, underwriter choice, withdrawal probability (the inverse Mills ratio generated from the probit model in column (2)), capacity for bundling, and firm characteristics. Following Lowry and Schwert (2000), we allow for asymmetry in the relationship between proceeds revisions and initial returns by using a piece-wise linear specification. Specifically, we include a second term that equals proceeds revisions if they are positive and zero otherwise. 13 The second term captures the marginal effect of positive revisions on initial returns. We also control for the previously documented positive relationship between IPO volume and initial return [Lowry and Schwert (2000)] by including the number of filings (across all industries) in active registration on a firm's offering date. Note that we distinguish this general 'hot market' relationship from bundling; bundling predicts that initial returns are lower, the more offerings subject to a common valuation factor an IPO can be bundled with. Equation [2] does not include the pre- or post-filing spillover measures, as these affect initial returns indirectly through the instrumented proceeds revision variable.

The 2SLS results are reported in column (5). ${ }^{4}$ The overall explanatory power of the regression is good, in view of the $R^{2}$ of $20.7 \%$. The coefficient estimated for log proceeds revisions is positive but not significant, whereas the coefficient estimated for positive-only revisions is strongly positive $(p<0.001)$. The implication is that initial returns are unrelated to negative proceeds revisions, but

\footnotetext{
${ }^{13}$ Both terms are treated as endogenous in the 2 SLS estimation. The positive-only term is instrumented from the firststage predicted values of proceeds revisions.

${ }^{14}$ For details regarding Heckman selectivity corrections in 2SLS models, see Maddala (1983), pp. 234-235.
} 
increase strongly in positive proceeds revisions. This asymmetry is consistent with Hanley's (1993) 'partial adjustment' phenomenon.

Interestingly, the Carter-Manaster rank variable is not significantly related to initial returns. Recall that in column (4), underwriter reputation is positively related to the extent of information acquisition, as measured by a firm's proceeds revisions. Thus, underwriter quality appears to influence initial returns indirectly through its effect on information production, rather than directly. The indirect effect is what we would expect in the Benveniste-Spindt (1989) framework, for more active and prestigious banks should have more leverage to extract information from investors, leading to more aggressive proceeds revisions. The direct effect is what we would expect in the Carter-Manaster (1990) and Booth-Smith (1986) framework which models prestigious underwriters as transferring 'certification' benefits rather than offering superior information production.

The inverse Mills ratio is positive and significant $(p=0.032)$, so as the probability of withdrawal increases, firms experience higher initial returns. This is inconsistent with the argument in Busaba, Benveniste, and Guo (2001), where a greater withdrawal probability is interpreted as providing issuers with more bargaining power in extracting information from investors (and so less money is left on the table). ${ }^{5}$ The economic magnitude of our effect, however, is small: a one standard deviation increase in the inverse Mills ratio (from 25.4\% to 47.5\%) increases initial returns only from $20.2 \%$ to $21.9 \%$.

One possible explanation for this result is a countervailing force implied by the Benveniste et al. theory. Holding the cost of information production/acquisition fixed, average percentage initial returns should be lower when there are more issuers present to share information costs. We have already documented that potential issuers are more likely to withdraw an attempted IPO when their

\footnotetext{
${ }^{15}$ Our estimation sample and system differ in important respects from Busaba, Benveniste, and Guo's. Busaba et al. use data from 1990 to 1992 only, and treat underwriter choice and filing revisions as exogenous. If we do likewise, we can reproduce their finding that initial returns decrease in the withdrawal probability. However, if we extend the sample period, or treat underwriter choice and filing revisions as endogenous, or both, we can no longer replicate this result.
} 
contemporaries are withdrawing theirs. Thus, characteristics that suggest a high probability of withdrawal imply that fewer contemporaneous offerings sharing a common factor will be completed and so fewer firms will be present to bear costs imposed indirectly via underpricing. But expected percentage underpricing must be sufficiently deep to support a number of firms "costlessly" acquiring information through a withdrawn offering, otherwise it will not be incentive compatible for investors to reveal private information in the first place.

We thus think of the bargaining power and cost-sharing theories as predicting countervailing effects on initial returns as a consequence of a higher probability of withdrawal. The sample at large suggests that the cost-sharing theory dominates. Further insight into the plausibility of this argument can be gained by discriminating between firms in nascent and mature industries. If the former are characterized by a greater reliance on intangible assets, which are less easily financed with debt, they will have fewer alternative sources of finance and so less bargaining power. Consistent with this distinction, we report in the next section that the direct relation between initial returns and the probability of withdrawal is concentrated among firms in nascent industries. Among firms in mature industries, the withdrawal probability has no statistically significant effect on initial returns.

We do not include the two dummies for a deal's position in the IPO wave, because - assuming underwriters do bundle IPOs - initial returns should be smoothed across a sequence of offerings subject to a common valuation factor and so the dummies should not be significant (indeed, they are not). Instead, we include a control for the capacity for bundling. The more offerings there are in an IPO wave, the more bundling can occur and so the lower are initial returns. In Table 5 we report the results of using the number of IPO filings in the first 180 days of an IPO wave to proxy for bundling capacity. As we will show in Section V, we obtain stronger (weaker) results if we extend (reduce) the length of time over which we assume bundling to occur. The coefficient estimate is negative, as predicted, and significant $(p=0.047)$. The coefficient suggests that each additional offering with which an IPO can be bundled reduces initial returns by 32 basis points. 
In contrast to these results regarding bundling, we find that initial returns increase in the number of filings (across all industries) in active registration on a firm's offering date $(p<0.001)$. This mirrors Ritter's (2000) findings on the effect of hot IPO market conditions on underpricing. The effect is relatively large: a one standard deviation increase in the number of registered offerings from the mean increases underpricing by nearly four percentage points.

The coefficient estimates for firm characteristics, included to control for firm-specific uncertainty, show that initial returns are higher in nascent industries $(p=0.002)$ and the more speculative the offering according to our PVGO index $(p<0.001)$. We also find that venture-backed IPOs are marginally more underpriced $(p=0.066)$, which contrasts with the findings reported in Megginson and Weiss (1991) for the 1980s. We do not include offer size in the initial return regression, as Habib and Ljungqvist (1998) show that initial returns decrease in offer size as a matter of identities, even when uncertainty is held constant. 16

\section{Summary}

The results presented in Table 5 are strongly consistent with the predictions of Benveniste, Busaba, and Wilhelm (2001) and our discussion in Section II. We have found

- that information production about common valuation factors spills over, affecting both the IPO decision and revisions in offer terms;

- that learning diminishes over a sequence of IPOs related by a common valuation factor, such that pioneers experience larger proceeds revisions than followers; and

- evidence consistent with investment banks spreading the cost of information production, in the form of underpricing, across multiple issuers.

\footnotetext{
${ }^{16}$ IPO proceeds clearly increase in the number of newly issued shares. In contrast, the post-issue price of a share is decreasing in that number, because the issuance of a greater number of new shares that are sold at a discount implies higher losses from dilution. The lower post-issue price, combined with an unchanged issue price absent any change in uncertainty, imply lower underpricing.
} 
In the next section, we report several additional tests that speak to the robustness of our results.

\section{ROBUSTNESS TESTS}

\section{Bundling and IPO waves}

Perhaps the most arbitrary elements of the analysis relate to our definitions for 'pioneer' firms and 'IPO waves'. The results for the withdrawal and proceeds revision equations shown in Table 5 assume that a pioneer is a firm whose filing is the first in its Fama-French industry for at least 180 days. If we change this window to 90 or 120 days, corresponding to the alternative definitions set out earlier in Table 4, the coefficient estimates change by no more than half a standard error. We thus continue to find that pioneers are more likely to withdraw than their followers, and that they are associated with significantly greater proceeds revisions conditional on completing their IPOs.

The results for the initial returns equation shown in Table 5 assume that the early part of a wave (during which bundling seems most plausible) lasts for 180 days following the pioneer's filing. If we lengthen this window to 360 days, the coefficient estimated for the bundling variable changes from $-0.0032(p=0.047)$ to $-0.004(p<0.001)$. If we shorten the window to 90 days, the coefficient estimate is -0.0018 , which is not significant. Thus the results reported in Table 5 suggest that if we are detecting bundling tactics, then they are carried out over relatively long horizons.

The bundling variable used in these specifications is the total number of firms that file in the first 90, 180, or 360 days after the pioneer's filing. This number could be an overestimate of the capacity for bundling, as it includes offerings lead-managed by banks that are not party to the effort

to spread the information production costs across a sequence of deals. Instead, we might require that an offering can only effectively be bundled with deals that involve one of its lead- or co-managers. With this narrower definition, bundling continues to have a significant and negative effect on initial returns, but only if we assume the early part of the wave to last for 360 days. 
All bundling counts used in Table 5 are, by construction, identical for each firm in the early part of a given wave: if the wave has 20 firms filing in its first $T$ days, then the bundling variable equals 20 for the pioneer and all followers during the first $T$ days. Implicitly, this assumes that underwriters have a good idea how many firms there will be in a wave, and spread the information production costs accordingly. A less demanding assumption would be to allow bundling with all firms (in the same Fama-French industry) that are in active registration on firm $i$ 's offer date. To illustrate the difference, if the rate of registrations increases over the first $T$ days of a wave, we now allow firms going public later to have more bundling candidates than those at the beginning of the wave. Again, we can distinguish between a bank-specific count and a general count. In either case, we find that bundling has a significant and negative effect on initial returns if we assume the early part of the wave to last for 360 days ( $p=0.035$ and $p<0.001$ for the bank-specific and general case, respectively).

Overall, our results are robust to alternative ways of capturing bundling capacity, especially when we allow windows of 180 or 360 days.

\section{Defining contemporaries}

As an alternative to defining contemporaries by Fama-French industry, we might use 3- or 4-digit SIC codes. In either case, our results are little changed in terms of signs and significance, except that the underpricing experience of contemporaries ceases to be significant in the withdrawal probability model. Coefficient estimates for the 4-digit SIC model are generally noisier than for the 3-digit SIC or Fama-French model.

Which model captures spillovers best? If we include spillover measures at the 3-digit SIC level in the Fama-French model of Table 5, we find that the same Fama-French variables are significant as in the Table 5 specification, while the 3-digit SIC variables are only occasionally significant. If 
we repeat the 'horse race' with spillovers measured at the 4-digit SIC level, the Fama-French variables are again generally significant while the 4-digit SIC variables virtually never are.

Taken together, these results suggest that our results are not driven by the way we define contemporaries, but that our Fama-French-based definition has more power to detect spillovers than SIC-based definitions.

\section{Sample period}

Our sample period includes the Internet-related hot issue market of 1999 and early 2000 which in many ways was extreme. Underpricing during this period averaged $63.7 \%$, the total amount of 'money left on the table' was $\$ 65.576$ billion (almost twice the total in the previous 14 years), and SIC code 737 (software and IT related services) alone accounted for $20 \%$ of IPO activity by gross proceeds. To investigate whether our results are driven by the inclusion of this extreme market, we re-estimate our model from Table 5 over the years 1985-1998. The results are unchanged in terms of signs and so continue to support the spillover and bundling predictions. The few changes in significance hardly affect our conclusions. The positive effect of the relative filing amount (the aggregate filing amount in a Fama-French industry divided by the aggregate filing amount of new registrants across all industries) on the probability of completing an IPO becomes significant $(p=0.021)$ when in Table 5 it was insignificant. This suggests that the rate of new registrations positively affects a firm's completion probability. Firms in nascent industries cease to be associated with higher-ranked underwriters in the column (3) specification. Pre-filing information, in the form of underpricing amongst firms in the same Fama-French industry, does affect proceeds revisions significantly $(p=0.002)$. The 'partial adjustment' effect of proceeds revisions on initial returns ceases to be asymmetric. More prestigious underwriters are associated with lower initial returns $(p<0.001)$, pointing to a direct 'certification' effect of top underwriters that works alongside the 
'information production' effect coming from proceeds revisions. Finally, the coefficient for bundling capacity in the column (5) specification drops in significance to $p=0.1$.

\section{Nascent vs. mature industries}

Benveniste et al. argue that information externalities associated with IPOs will be more severe, and therefore command more attention from an intermediary, in developing industries where value depends more heavily on growth opportunities and other intangible assets. In new industries public offerings are often associated with the introduction of new technology or intangibles over which a market consensus has not been achieved. In such cases, feedback from the primary market is quite valuable on the margin, both to the pioneering firm and those who might follow. Thus both the magnitude of the externality problem and the potential benefits from its resolution are likely to be more pronounced. We investigate this hypothesis by partitioning the sample into 'nascent' and mature industries and re-estimating the Table 5 specification in each sub-sample.

The results lend further support to the predictions of the Benveniste et al. model. The regressions of equations [1] and [2] have much greater explanatory power in the subsample of nascent industries: in the proceeds revisions regressions, $R^{2}$ is $18.2 \%$ for nascent industries vs. $4.4 \%$ for mature firms; in the initial return regressions, $R^{2}$ is $21.7 \%$ for nascent industries vs. $11.1 \%$ for mature firms. This is consistent with firms in nascent industries benefiting more from the information production of contemporaneous offerings. The coefficient estimates confirm this interpretation: generally speaking, firms in nascent industries are more sensitive to the spillover measures than mature companies. For instance, in the proceeds revision regressions, the relative industry return has a coefficient of 0.765 in the nascent industries vs. 0.378 among mature companies, so a given degree of outperformance by a firm's own industry translates into a larger proceeds revision in nascent industries. Unlike mature companies, firms in nascent industries revise their proceeds up in response to information revealed in increases in the rate of new registrations in 
their own industry $(p=0.006)$. In the initial return regression for nascent industries, the positive effect of the withdrawal probability (the inverse Mills ratio) is fifteen times larger than in mature industries. As discussed earlier, this suggests that the cost-sharing argument of Benveniste et al. dominates the bargaining argument of Busaba et al. in our sample.

Most of the coefficients have the same sign in the two subsamples. The main exception concerns pioneers in the proceeds revision. Compared to their followers, pioneers in nascent industries have smaller proceeds revisions $(p=0.03)$ while pioneers in mature industries have larger proceeds revisions $(p=0.005) . \stackrel{17}{1}$ One possible interpretation of this finding follows from our earlier conjecture that mature industries depend less on intangible assets and therefore should have more fallback financing opportunities. If so, this finding might indicate that pioneers in mature industries have more bargaining power with investors and therefore suffer a less severe partial adjustment to the acquisition of private information.

\section{Pre-filing windows}

The pre-filing information that we use in the underwriter choice and proceeds revisions regressions is measured over the three months (12 weeks) before firm $i$ 's filing date. Using shorter windows of between 1 and 11 weeks, we find similar results: underwriter choice continues to be related to prefiling market conditions (except for the four-week case) while proceeds revisions are related only to spillovers occurring during the bookbuilding phase and not to pre-filing information.

\footnotetext{
${ }^{17} \mathrm{We}$ also find differences in the effect of VC-backing and underwriter choice in the initial return regressions. In nascent industries, initial returns increase in the instrumented Carter-Manaster rank $(p=0.019)$ while VC-backing has no significant effect. In mature industries, initial returns decrease in the instrumented Carter-Manaster rank $(p=0.028)$ while VC-backing has a positive effect ( $p=0.002$ ). These differences are driven by the 1999/2000 hot issue market. When we restrict the estimation to the 1985-1998 period, the positive effects of underwriter rank in nascent industries and of VC-backing in mature industries disappear.
} 


\section{CONCLUSION}

Our empirical analysis suggests three principal conclusions:

- Firms attempting IPOs learn from the experience of their contemporaries. These information spillovers affect the decision whether to carry through with an offering and revisions in offer terms. Although we cannot measure them directly, we think it stands to reason that firms considering an IPO would enjoy similar benefits.

- Learning diminishes over a sequence of IPOs related by a common valuation factor, such that pioneers experience larger proceeds revisions than followers. In other words, potential issuers incorporate the experience of their contemporaries in the initial terms proposed in the preliminary prospectus.

- The evidence is broadly consistent with investment banks maintaining sufficient market power to spread the cost of information production, in the form of underpricing, across multiple issuers. One apparent consequence of this behavior is that while initial returns and IPO volume are positively correlated in the aggregate, the correlation is negative among contemporaneous offerings subject to a common valuation factor.

As such, our findings are consistent with the Benveniste, Busaba, and Wilhelm (2001) argument that the dynamics of volume and initial returns in primary equity markets reflect, at least in part, an institutional response to information externalities. 


\section{REFERENCES}

Anand, B. and A. Galetovic, 2000, Information, non-excludability, and financial market structure, Journal of Business 73, 357-402.

Beatty, R. P. and J. R. Ritter, 1986, Investment banking, reputation, and the underpricing of initial public offerings, Journal of Financial Economics 15, 213-232.

Benveniste, L. and W. Busaba, 1997, Bookbuilding versus fixed price: An analysis of competing strategies for marketing IPOs, Journal of Financial and Quantitative Analysis 32, 383-403.

Benveniste, L., W. Busaba and W. J. Wilhelm, 2001, Information externalities in primary equity markets, Journal of Financial Intermediation, forthcoming.

Benveniste, L. and P. Spindt, 1989, How investment bankers determine the offer price and allocation of initial public offerings, Journal of Financial Economics 24, 343-362.

Booth, J. R. and R. Smith, 1986, Capital raising, underwriting and the certification hypothesis, Journal of Financial Economics 15, 261-281.

Busaba, W., L. Benveniste and R. Guo, 2001, The withdrawal of initial public offerings during the premarket, Journal of Financial Economics 60, 73-102.

Carter, R. B. and S. Manaster, 1990, Initial public offerings and underwriter reputation, Journal of Finance 45, 1045-1067.

Carter, R. B., F. Dark and A. Singh, 1998, Underwriter reputation, initial returns, and the long-run performance of IPO stocks, Journal of Finance 53, 285-311.

Cornelli, F. and D. Goldreich, 2001, Bookbuilding and strategic allocation. Journal of Finance, forthcoming.

Dunbar, C., 1998, The choice between firm-commitment and best-efforts offering methods in IPOs: the effect of unsuccessful offers, Journal of Financial Intermediation 7, 60-90.

Fama, E. F. and K. R. French, 1997, Industry costs of equity, Journal of Financial Economics 43, 153-194.

Habib, M. A. and A. P. Ljungqvist, 1998, Underpricing and IPO proceeds: A note, Economics Letters 61, 381-383.

Habib, M. A. and A. P. Ljungqvist, 2001, Underpricing and entrepreneurial wealth losses in IPOs: theory and evidence, Review of Financial Studies 14, 433-458.

Hanley, K. W., 1993, Underpricing of initial public offerings and the partial adjustment phenomenon. Journal of Financial Economics 37, 239-257.

Hanley, K. W. and W. J. Wilhelm, 1995, Evidence on the strategic allocation of initial public offerings. Journal of Financial Economics 37, 239-257. 
Hoffman-Burchardi, U., 2001, Clustering of initial public offerings, information revelation and underpricing, European Economic Review 45, 353-383.

Ibbotson, R. and J. R. Ritter, 1995, Initial public offerings, in: R. Jarrow, V. Maksimovic, and W. Ziemba (eds.), Handbooks of Operations Research and Management Science, Amsterdam: NorthHolland.

Lerner, J., 1994, Venture capitalists and the decision to go public, Journal of Financial Economics 35, 293-316.

Ljungqvist, A. P., T. Jenkinson and W. J. Wilhelm, 2001, Global integration in primary equity markets: the role of U.S. banks and U.S. investors. Review of Financial Studies, forthcoming.

Ljungqvist, A. P. and W. J. Wilhelm, 2001, IPO allocations: discriminatory or discretionary? Working Paper, New York University.

Loughran, T., and J. Ritter, 2000, Why don't issuers get upset about leaving money on the table in IPOs? Review of Financial Studies, forthcoming.

Lowry, M. and G. W. Schwert, 2000, IPO market cycles: bubbles or sequential learning? Working Paper, University of Rochester.

Lowry, M. and G. W. Schwert, 2001, Biases in the IPO pricing process. Working Paper, University of Rochester.

Maddala, G. S, 1983, Limited-dependent and qualitative variables in econometrics, Cambridge University Press.

Maksimovic, V. and P. Pichler 2001, Technological innovation and initial public offerings, Review of Financial Studies 14, 459-494.

Megginson, W. and K. Weiss, 1991, Venture capitalist certification in initial public offerings, Journal of Finance 46, 879-903.

Persons, J. and V. Warther, 1997, Boom and bust patterns in the adoption of financial innovations, Review of Financial Studies 10, 939-968.

Pichler, P. and W. J. Wilhelm, 2000, A theory of the syndicate: Forms follows function. Journal of Finance, forthcoming.

Sherman, A. and S. Titman, 2001, Building the IPO order book: Underpricing and participation limits with costly information. Journal of Financial Economics, forthcoming.

Tufano, P., 1989, Financial innovation and first-mover advantages, Journal of Financial Economics 25, 213-240.

White, H., 1980, A heteroskedasticity-consistent covariance matrix estimator and a direct test for heteroskedasticity, Econometrica 48, 817-838 
Table 1.

Summary statistics for sample of IPOs completed or withdrawn during January 1985-December 2000.

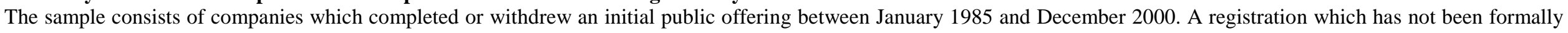

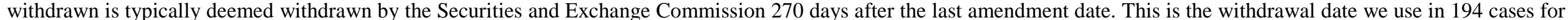

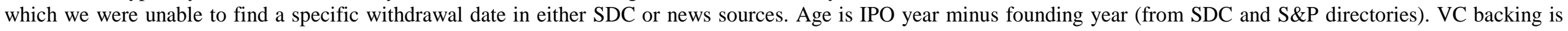

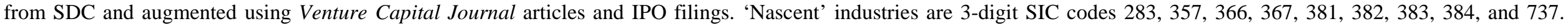

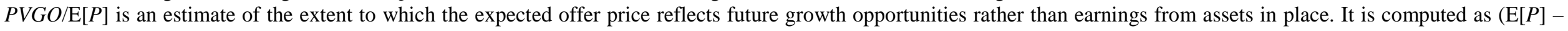

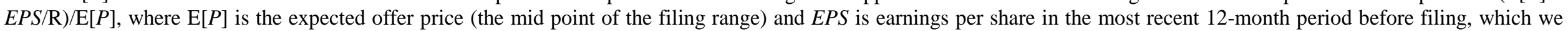

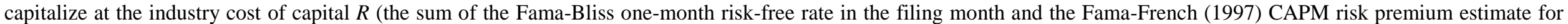

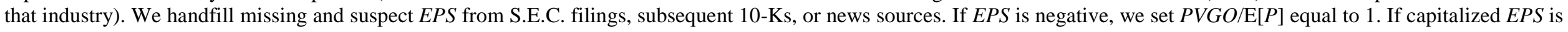

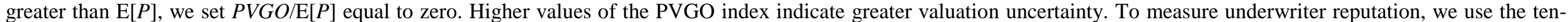

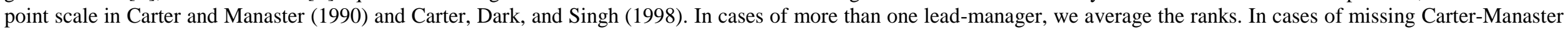

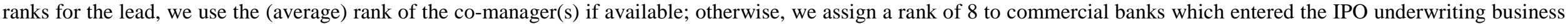

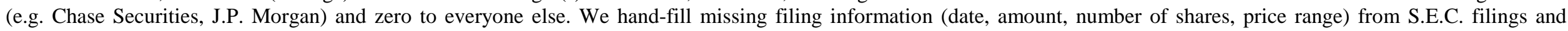

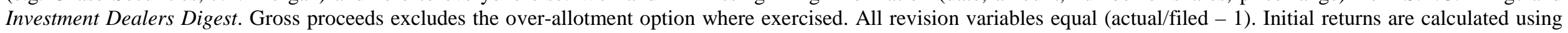

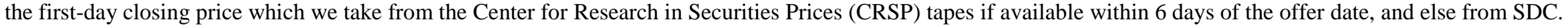

\begin{tabular}{|c|c|c|c|c|c|c|c|c|c|c|c|c|}
\hline & \multicolumn{6}{|c|}{ Completed offerings } & \multicolumn{6}{|c|}{ Withdrawn offerings } \\
\hline & $\begin{array}{r}\text { No. of } \\
\text { obs. }\end{array}$ & Mean & Std. Dev. & Min & Median & $\operatorname{Max}$ & $\begin{array}{c}\text { No. of } \\
\text { obs. } \\
\end{array}$ & Mean & Std. Dev. & Min & Median & $\operatorname{Max}$ \\
\hline Number of firms & 6,181 & & & & & & 1,422 & & & & & \\
\hline \multicolumn{13}{|l|}{ Firm characteristics } \\
\hline Age at IPO (years) & 4,450 & 12.79 & 19.52 & 0 & 7 & 182 & & & & & & \\
\hline VC-backed (fraction) & 6,181 & 0.37 & & & & & & & & & & \\
\hline Nascent inds. (fraction) & 6,181 & 0.34 & & & & & 1,352 & 0.30 & & & & \\
\hline$P V G O / E[P]$ & 6,174 & 0.71 & 0.33 & 0 & 0.82 & 1 & & & & & & \\
\hline \multicolumn{13}{|l|}{ Offering characteristics } \\
\hline Carter-Manaster rank & 6,181 & 6.88 & 3.01 & 0 & 8.75 & 9 & 1,422 & 6.07 & 3.67 & 0 & 8 & 9 \\
\hline Filing amt. (\$m) & 6,111 & 60.989 & 202.496 & 0.060 & 28.000 & 10440.000 & 1,388 & 51.564 & 94.433 & 0.100 & 30.300 & 2475.000 \\
\hline No. shares filed & 6,112 & $4,347,128$ & $10,900,000$ & 10,000 & $2,500,000$ & $360,000,000$ & & & & & & \\
\hline $\mathrm{E}[P](\$ /$ share $)$ & 6,174 & 11.62 & 4.50 & 0.01 & 11.50 & 55.50 & & & & & & \\
\hline Gross proceeds (\$m) & 6,181 & 63.565 & 216.826 & 0.069 & 27.550 & 10620.000 & & & & & & \\
\hline No. shares sold & 6,181 & $4,487,419$ & $11,000,000$ & 11,500 & $2,500,000$ & $360,000,000$ & & & & & & \\
\hline Offer price (\$/share) & 6,181 & 11.71 & 5.23 & 0.01 & 11.00 & 56.50 & & & & & & \\
\hline Proceeds revision & 6,111 & 0.0387 & 0.3118 & -0.9770 & 0.0000 & 3.9587 & & & & & & \\
\hline Share revision & 6,112 & 0.0247 & 0.2236 & -0.9800 & 0.0000 & 9.4167 & & & & & & \\
\hline Price revision & 6,174 & 0.0096 & 0.2211 & -0.6774 & 0.0000 & 3.4444 & & & & & & \\
\hline Initial return & 6,136 & 0.2022 & 0.4257 & -0.4327 & 0.0750 & 6.2667 & & & & & & \\
\hline
\end{tabular}


Table 2.

Industry breakdown.

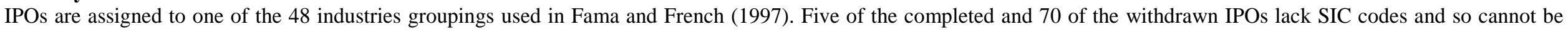
assigned to a Fama-French industry.

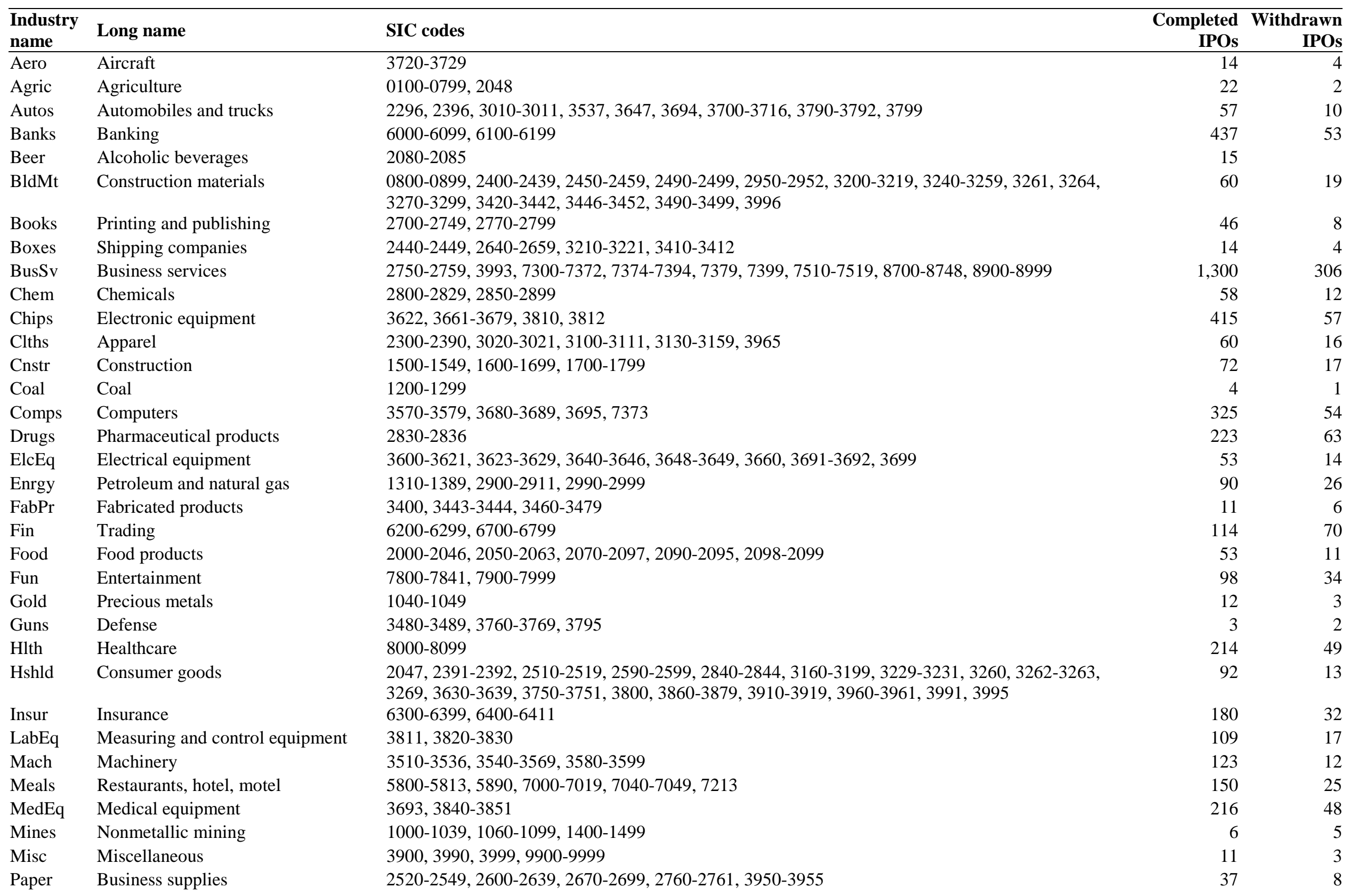


PerSv

RlEs

Rtail

Rubbr

Ships

Smoke

Soda

Steel

Telcm

Toys

Trans

Txtls

Util

Whlsl
Real estate

Retail

Rubber and plastic products

Shipbuilding, railroad equipment

Tobacco products

Candy and soda

Steel works etc.

Telecommunications

Recreational products

Transportation

Textiles

Utilities

Wholesale
7020-7021, 7030-7039, 7200-7212, 7215-7299, 7395, 7500, 7520-7549, 7600-7699, 8100-8199, 8200-8299, 8300-8399, 8400-8499, 8600-8699, 8800-8899

$6500-6553$

5200-5299, 5300-5399, 5400-5499, 5500-5599, 5600-5699, 5700-5736, 5900-5999

3000, 3050-3099

$3730-3731,3740-3743$

2100-2199

2064-2068, 2086-2087, 2096-2097

$3300-3369,3390-3399$

4800-4899

0900-0999, 3650-3652, 3732, 3930-3949

4000-4099, 4100-4199, 4200-4299, 4400-4499, 4500-4599, 4600-4699, 4700-4799

2200-2295, 2297-2299, 2393-2395, 2397-2399

4900-4999

5000-5099, 5100-5199
36 
Table 3.

Panel A: Descriptive statistics for pre-filing spillover variables.

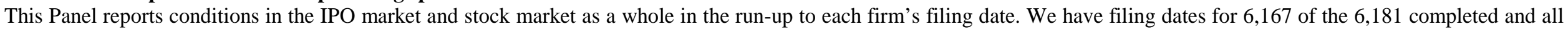

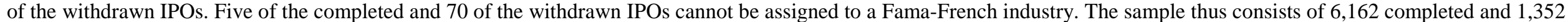

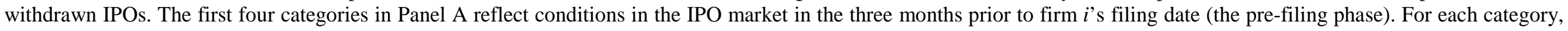

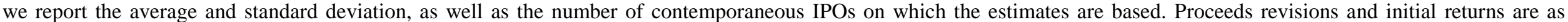

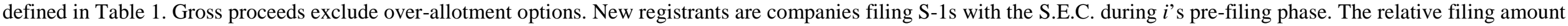

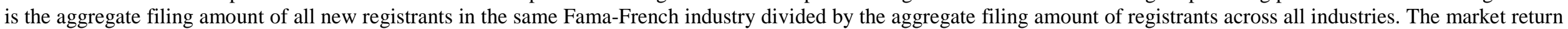

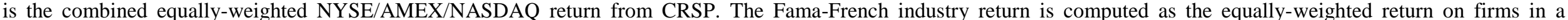

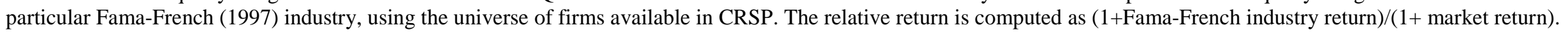

\begin{tabular}{|c|c|c|c|c|c|c|c|c|c|c|}
\hline & \multicolumn{5}{|c|}{ Completed offerings $(\mathrm{N}=6,162)$} & \multicolumn{5}{|c|}{ Withdrawn offerings $(\mathrm{N}=1,352)$} \\
\hline & Mean & Std. Dev. & Min & Median & Max & Mean & Std. Dev. & Min & Median & Max \\
\hline \multicolumn{11}{|l|}{ Proceeds revisions } \\
\hline Mean & 0.0680 & 0.2121 & -0.8649 & 0.0226 & 3.9587 & 0.0727 & 0.2051 & -0.6547 & 0.0133 & 1.8000 \\
\hline St.dev. & 0.1910 & 0.1694 & 0 & 0.1855 & 2.4457 & 0.1923 & 0.1745 & 0 & 0.1843 & 1.2255 \\
\hline No. of firms revising their proceeds & 10 & 15 & 0 & 4 & 86 & 12 & 18 & 0 & 4 & 85 \\
\hline \multicolumn{11}{|l|}{ Initial returns } \\
\hline Mean & 0.2094 & 0.3090 & -0.2500 & 0.1234 & 2.5648 & 0.2507 & 0.3751 & -0.3214 & 0.1138 & 2.4100 \\
\hline St.dev. & 0.1998 & 0.2955 & 0 & 0.1047 & 2.5278 & 0.2350 & 0.3433 & 0 & 0.1009 & 1.9223 \\
\hline No. of firms going public & 10 & 15 & 0 & 5 & 86 & 12 & 18 & 0 & 4 & 85 \\
\hline \multicolumn{11}{|l|}{ Gross proceeds of new registrants } \\
\hline Mean $(\$ m)$ & 51.095 & 93.805 & 0 & 33.652 & 4266.600 & 56.762 & 91.294 & 0 & 38.988 & 1687.993 \\
\hline St.dev. & 51.807 & 141.757 & 0 & 21.203 & 2649.802 & 59.960 & 194.298 & 0 & 23.316 & 2570.420 \\
\hline No. of new registrants & 13 & 21 & 0 & 6 & 148 & 18 & 30 & 0 & 6 & 148 \\
\hline Relative filing amount & 0.0719 & 0.0855 & 0 & 0.0359 & 0.5764 & 0.0784 & 0.0962 & 0 & 0.0340 & 0.5103 \\
\hline \multicolumn{11}{|l|}{ Gross proceeds of withdrawers } \\
\hline Mean $(\$ m)$ & 22.345 & 48.438 & 0 & 0 & 1350.000 & 27.371 & 41.902 & 0 & 3.963 & 378.000 \\
\hline St.dev. & 8.396 & 22.217 & 0 & 0 & 255.690 & 10.800 & 24.135 & 0 & 0 & 255.690 \\
\hline No. of withdrawn offerings & 1 & 3 & 0 & 0 & 42 & 2 & 4 & 0 & 1 & 44 \\
\hline \multicolumn{11}{|l|}{ Market returns } \\
\hline Market return: mean & 0.1261 & 0.1105 & -0.2948 & 0.1231 & 0.4911 & 0.0726 & 0.1005 & -0.2889 & 0.0679 & 0.4189 \\
\hline Market return: st.dev. & 0.0052 & 0.0022 & 0.0022 & 0.0048 & 0.0226 & 0.0058 & 0.0028 & 0.0022 & 0.0052 & 0.0256 \\
\hline Fama-French industry return: mean & 0.1096 & 0.1558 & -0.4017 & 0.0927 & 1.7411 & 0.0881 & 0.1753 & -0.4152 & 0.0592 & 1.5403 \\
\hline Fama-French industry return: st.dev. & 0.0078 & 0.0042 & 0.0018 & 0.0069 & 0.0399 & 0.0088 & 0.0054 & 0.0021 & 0.0074 & 0.0358 \\
\hline Relative return & 0.9861 & 0.0995 & 0.6128 & 0.9769 & 1.9590 & 1.0115 & 0.0990 & 0.6770 & 0.9992 & 1.9922 \\
\hline
\end{tabular}


Table 3.

Panel B: Descriptive statistics for post-filing spillover variables.

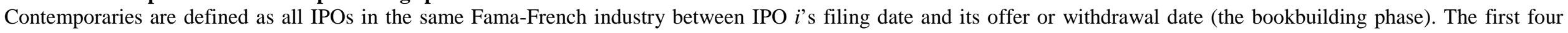

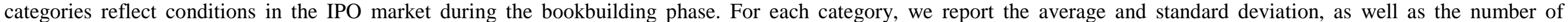

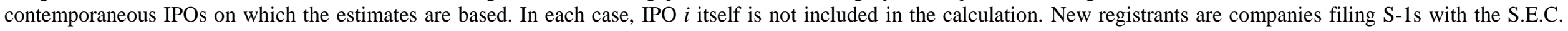

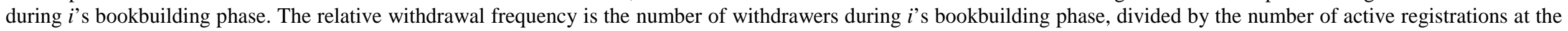
time of $i$ 's S.E.C. filing. (This ratio need not be less than one.)

\begin{tabular}{|c|c|c|c|c|c|c|c|c|c|c|}
\hline & \multicolumn{5}{|c|}{ Completed offerings $(\mathrm{N}=6,162)$} & \multicolumn{5}{|c|}{ Withdrawn offerings $(\mathrm{N}=1,352)$} \\
\hline & Mean & Std. Dev. & Min & Median & Max & Mean & Std. Dev. & Min & Median & Max \\
\hline \multicolumn{11}{|l|}{ Proceeds revisions } \\
\hline Mean & 0.0461 & 0.1971 & -0.9000 & 0 & 3.9587 & 0.0083 & 0.1518 & -0.6000 & 0 & 0.8667 \\
\hline St.dev. & 0.1736 & 0.1667 & 0 & 0.1617 & 1.5299 & 0.2259 & 0.1573 & 0 & 0.2337 & 1.0457 \\
\hline No. of firms revising their proceeds & 10 & 20 & 0 & 4 & 483 & 25 & 42 & 0 & 9 & 420 \\
\hline \multicolumn{11}{|l|}{ Initial returns } \\
\hline Mean & 0.1920 & 0.2923 & -0.3000 & 0.1020 & 3.1483 & 0.1867 & 0.2532 & -0.3214 & 0.1036 & 2.8757 \\
\hline St.dev. & 0.1874 & 0.2891 & 0 & 0.0865 & 3.1315 & 0.2378 & 0.2953 & 0 & 0.1341 & 3.0008 \\
\hline No. of firms going public & 10 & 20 & 0 & 4 & 483 & 25 & 43 & 0 & 9 & 419 \\
\hline \multicolumn{11}{|l|}{ Gross proceeds of new registrants } \\
\hline Mean $(\$ m)$ & 49.120 & 91.277 & 0 & 32.041 & 2450.000 & 67.810 & 167.890 & 0 & 44.867 & 4266.600 \\
\hline St.dev. & 47.428 & 160.953 & 0 & 15.981 & 4183.669 & 70.342 & 171.085 & 0 & 34.014 & 2919.502 \\
\hline No. of new registrants & 13 & 27 & 0 & 4 & 662 & 32 & 56 & 0 & 11 & 572 \\
\hline Relative filing amount & 0.0737 & 0.0940 & 0 & 0.0340 & 0.6895 & 0.0758 & 0.0908 & 0 & 0.0345 & 0.5224 \\
\hline \multicolumn{11}{|l|}{ Gross proceeds of withdrawers } \\
\hline Mean $(\$ m)$ & 21.366 & 42.977 & 0 & 0 & 1350.000 & 40.750 & 57.434 & 0 & 29.809 & 1239.600 \\
\hline St.dev. & 8.365 & 32.841 & 0 & 0 & 1410.685 & 23.322 & 64.355 & 0 & 9.558 & 1747.119 \\
\hline No. of withdrawn offerings & 2 & 6 & 0 & 0 & 149 & 9 & 18 & 0 & 2 & 116 \\
\hline Relative withdrawal frequency & 0.0932 & 0.1927 & 0 & 0 & 5.0000 & 0.4385 & 0.5613 & 0 & 0.3000 & 5.0000 \\
\hline \multicolumn{11}{|l|}{ Market returns } \\
\hline Market return: mean & 0.0651 & 0.1072 & -0.2953 & 0.0454 & 1.7208 & 0.2062 & 0.4053 & -0.2667 & 0.1195 & 7.8572 \\
\hline Market return: st.dev. & 0.0052 & 0.0026 & 0 & 0.0045 & 0.0351 & 0.0072 & 0.0037 & 0.0020 & 0.0056 & 0.0210 \\
\hline Fama-French industry return: mean & 0.0771 & 0.1581 & -0.4413 & 0.0472 & 2.1636 & 0.1859 & 0.5111 & -0.5837 & 0.0816 & 7.4838 \\
\hline Fama-French industry return: st.dev. & 0.0079 & 0.0047 & 0 & 0.0069 & 0.0406 & 0.0107 & 0.0070 & 0 & 0.0082 & 0.0445 \\
\hline Relative return & 1.0098 & 0.0812 & 0.6014 & 1.0018 & 2.1995 & 0.9746 & 0.1732 & 0.5151 & 0.9692 & 2.6132 \\
\hline
\end{tabular}


Table 4.

IPO waves.

We consider three different ways to identify the beginning of a sequence of IPOs sharing a common valuation factor (an 'IPO wave'). For each Fama-French industry, we identify all S.E.C. filings not preceded by filings in the same industry in the previous 180, 120, or 90 days. We denote such filers 'pioneers'. All other IPOs are 'followers'. We distinguish between 'early' and 'late' followers in three different ways. Early followers are those which file within 90, 180 or 360 days of a pioneer's filing date. The right-hand side panel shows the distributions of early followers under each definition.

\begin{tabular}{|c|c|c|c|c|c|c|c|c|c|}
\hline \multirow{2}{*}{$\begin{array}{l}\text { Wave begins when no } \\
\text { S.E.C. filing in same } \\
\text { Fama-French industry } \\
\text { in the previous... }\end{array}$} & \multirow[t]{2}{*}{$\begin{array}{r}\text { total } \\
\text { number of } \\
\text { waves }\end{array}$} & begun by a p & neer who & \multirow[t]{2}{*}{$\begin{array}{l}\text { Number of } \\
\text { followers } \\
\text { in the next }\end{array}$} & \multirow{2}{*}{ Mean } & \multirow[b]{2}{*}{ Std. } & \multirow{2}{*}{\multicolumn{2}{|c|}{ Min Median }} & \multirow[b]{2}{*}{ Max } \\
\hline & & went public & withdrew & & & & & & \\
\hline \multirow[t]{4}{*}{... 180 days } & 311 & 240 & 71 & & & & & & \\
\hline & & & & ...90 days & 0.9 & 1.4 & 0 & 0 & 11 \\
\hline & & & & $\ldots 180$ days & 1.8 & 2.4 & 0 & 1 & 19 \\
\hline & & & & ... 360 days & 3.7 & 5.5 & 0 & 2 & 40 \\
\hline \multirow[t]{4}{*}{$\ldots 120$ days } & 491 & 379 & 112 & & & & & & \\
\hline & & & & ...90 days & 2.7 & 3.4 & 0 & 1 & 16 \\
\hline & & & & ... 180 days & 5.5 & 7.5 & 0 & 3 & 37 \\
\hline & & & & ... 360 days & 10.3 & 15.6 & 0 & 4 & 93 \\
\hline \multirow[t]{4}{*}{... 90 days } & 668 & 531 & 137 & & & & & & \\
\hline & & & & ...90 days & 6.0 & 6.9 & 0 & 3 & 26 \\
\hline & & & & $\ldots 180$ days & 11.1 & 13.8 & 0 & 5 & 52 \\
\hline & & & & ... 360 days & 17.8 & 24.8 & 0 & 6 & 122 \\
\hline
\end{tabular}


Table 5.

System estimation.

Endogenous right-hand-side variables are instrumented using 2SLS. Pre-filing spillover variables are computed using all firms in the same Fama-French industry during the three months before firm i's filing date. Bookbuilding spillover variables are computed using all firms in the same Fama-French industry between $i$ 's filing and offer or withdrawal date. The definition of each spillover variable is as in Table 3. IPO wave and bundling variables are defined as in Table 4. 'Firms in active registration' refers to companies who had neither completed nor withdrawn a filed offering on firm i's offer date. Company/offer characteristics are defined as in Table 1. Column (2) is the first stage of the Heckman 2SLS model in column (5). Standard errors are adjusted for time clustering by assuming that observations are independent for companies at different points in time, but not necessarily for companies which go public or withdraw in the same month. They are more conservative than White (1980) standard errors. ${ }^{* * *},{ }^{* *},{ }^{*},{ }^{\dagger}=$ significant at $0.1 \%, 1 \%, 5 \%$ or $10 \%$ (two-sided), respectively.

\begin{tabular}{|c|c|c|c|c|c|}
\hline \multirow[t]{2}{*}{ Dependent variable: } & $\begin{array}{c}(1) \\
\text { Carter- } \\
\text { Manaster } \\
\text { rank }\end{array}$ & $\begin{array}{c}(2) \\
\text { Dummy=1 } \\
\text { if IPO } \\
\text { completed }\end{array}$ & $\begin{array}{c}(3) \\
\text { Carter- } \\
\text { Manaster } \\
\text { rank }\end{array}$ & $\begin{array}{c}(4) \\
\ln (\text { proceeds } \\
\text { revision) }\end{array}$ & $\begin{array}{l}(5) \\
\text { Initial } \\
\text { return }\end{array}$ \\
\hline & OLS & Probit & OLS & 2SLS & 2SLS \\
\hline \multicolumn{6}{|l|}{ Endogenous variables } \\
\hline $\ln ($ proceeds revision) & & & & & $\begin{array}{l}0.204 \\
0.174\end{array}$ \\
\hline $\ln$ (proceeds revision) if positive, 0 else & & & & & $\begin{array}{l}2.193^{\text {*** }} \\
0.382\end{array}$ \\
\hline Carter-Manaster rank & & $\begin{array}{l}0.027^{*} \\
0.013\end{array}$ & & $\begin{array}{l}0.039^{* *} \\
0.013\end{array}$ & $\begin{array}{l}0.002 \\
0.003\end{array}$ \\
\hline Inverse Mills ratio & & & & & $\begin{array}{l}0.079^{*} \\
0.037\end{array}$ \\
\hline \multicolumn{6}{|l|}{ Pre-filing spillover variables } \\
\hline Average initial returns & $\begin{array}{c}-0.442^{* * *} \\
0.119\end{array}$ & & $\begin{array}{c}-0.381^{* *} \\
0.133\end{array}$ & $\begin{array}{l}0.032 \\
0.031\end{array}$ & \\
\hline Relative filing amount & $\begin{array}{l}1.142^{* * *} \\
0.417\end{array}$ & & $\begin{array}{l}1.314^{* *} \\
0.454\end{array}$ & $\begin{array}{r}-0.008 \\
0.079\end{array}$ & \\
\hline \multicolumn{6}{|l|}{ Bookbuilding spillover variables } \\
\hline Average proceeds revision & & $\begin{array}{l}0.751^{\text {*** }} \\
0.156\end{array}$ & & $\begin{array}{l}0.241^{\text {*** }} \\
0.035\end{array}$ & \\
\hline St.dev. proceeds revision & & $\begin{array}{c}-1.074^{* * *} \\
0.159\end{array}$ & & $\begin{array}{c}-0.102^{*} \\
0.044\end{array}$ & \\
\hline Average initial returns & & $\begin{array}{l}0.988^{* * *} \\
0.244\end{array}$ & & $\begin{array}{l}0.120^{* * *} \\
0.031\end{array}$ & \\
\hline St.dev. initial returns & & $\begin{array}{c}-1.115^{* * *} \\
0.223\end{array}$ & & $\begin{array}{c}-0.030 \\
0.040\end{array}$ & \\
\hline Relative filing amount & & 0.290 & & 0.027 & \\
\hline Relative withdrawal frequency & & $\begin{array}{c}0.283 \\
-1.756^{\text {*** }}\end{array}$ & & 0.065 & \\
\hline Relative return & & $\begin{array}{l}0.188 \\
1.109^{* * *} \\
0.337\end{array}$ & & $\begin{array}{l}0.521^{* * * *} \\
0.063\end{array}$ & \\
\hline
\end{tabular}




\begin{tabular}{|c|c|c|c|c|c|}
\hline Column: & (1) & (2) & (3) & (4) & (5) \\
\hline \multicolumn{6}{|l|}{ IPO wave/bundling } \\
\hline Dummy $=1$ if pioneer (180-day window) & & $-0.508^{* * *}$ & & $0.055^{* *}$ & \\
\hline Dummy $=1$ if early follower (next 180 days) & & $\begin{array}{c}0.123 \\
-0.215^{* *}\end{array}$ & & $\begin{array}{r}0.018 \\
-0.001\end{array}$ & \\
\hline & & 0.082 & & 0.016 & \\
\hline No. of filings in first 180 days of wave & & & & & $\begin{array}{c}-0.0032^{*} \\
0.0016\end{array}$ \\
\hline \multicolumn{6}{|l|}{ Hot issue market } \\
\hline No. of all filings in active registration & & & & & $\begin{array}{l}0.0007^{* * *} \\
0.0001\end{array}$ \\
\hline \multicolumn{6}{|l|}{ Company/offer characteristics } \\
\hline $\ln ($ filing amount $)$ & $\begin{array}{l}1.606^{* * *} \\
0.044\end{array}$ & & $\begin{array}{l}1.514^{* * *} \\
0.048\end{array}$ & $\begin{array}{c}-0.065^{* *} \\
0.021\end{array}$ & \\
\hline Dummy=1 if VC-backed & & & $1.361^{* * *}$ & $-0.034^{\dagger}$ & $0.029^{\dagger}$ \\
\hline Dummy=1 if in 'nascent' industry & $0.486^{* * *}$ & $0.093^{*}$ & $\begin{array}{l}0.067 \\
0.195^{* *}\end{array}$ & $\begin{array}{l}0.020 \\
0.018\end{array}$ & $\begin{array}{l}0.015 \\
0.034^{* *}\end{array}$ \\
\hline$P V G O / \mathrm{E}[P]$ & 0.072 & 0.046 & $\begin{array}{c}0.074 \\
-1.335^{* * *}\end{array}$ & $\begin{array}{l}0.012 \\
0.070^{* * *}\end{array}$ & $\begin{array}{l}0.011 \\
0.084^{* * *}\end{array}$ \\
\hline Constant & $\begin{array}{l}1.358^{* * *} \\
0.201\end{array}$ & $\begin{array}{l}0.201 \\
0.356\end{array}$ & $\begin{array}{l}0.105 \\
2.281^{\text {**** }} \\
0.239\end{array}$ & $\begin{array}{c}0.020 \\
-0.650^{* * * *} \\
0.069\end{array}$ & $\begin{array}{c}0.016 \\
-0.098^{* * *} \\
0.037\end{array}$ \\
\hline \multicolumn{6}{|l|}{ Diagnostics } \\
\hline$R^{2} /$ McFadden's $R^{2}$ & $39.1 \%$ & $19.7 \%$ & $41.4 \%$ & $9.3 \%$ & $20.7 \%$ \\
\hline Test: all coefficients $=0$ ( $p$-value $)$ & $<0.001$ & $<0.001$ & $<0.001$ & $<0.001$ & $<0.001$ \\
\hline No. of observations & 7,491 & 7,429 & 6,102 & 6,061 & 6,061 \\
\hline
\end{tabular}

